\title{
PENGARUH GREEN MARKETING MIX TERHADAP GREEN PRODUCT PURCHASE INTENTION PADA PRODUK INNISFREE DI JAKARTA DENGAN CONSUMER'S ATTITUDE SEBAGAI VARIABEL MEDIASI
}

\author{
Stevany Febriani \\ Program Studi Magister Manajemen Universitas Tarumanagara \\ stevanyfebriani22@gmail.com
}

\begin{abstract}
This study aimed to know the responses of the people about green marketing towards green product purchase intention on Innisfree products with consumer's attitude towards green product as the mediating variable. The variables used were green product, green price, green place, green promotion, green product purchase intention and consumer's attitude. This study uses quantitative method. The data collection technique use questionnaires distributed to 400 respondents namely Innisfree consumers in Jakarta with purposive sampling method. The analysis method that used in this study was path analysis. The result showed that green marketing mix positively and significantly affect to consumer's attitude and consumer's attitude positively and significantly affect green product purchase intention. The partial green product and green price $\mathrm{x}$ positively and significantly affect the green product purchase intention, green place and green promotion no significant effect to green product purchase intention. Consumer's attitude positively and significantly affect the green product purchase intention on Innisfree product. Consumer's attitude is fully mediated the green place and green promotion affect on green product purchase intention and partial mediated the green product and green price affect on green product purchase intention.
\end{abstract}

\begin{abstract}
Abstrak : Penelitian ini bertujuan untuk mengetahui respon konsumen tentang green marketing terhadap green product purchase intention pada produk Innisfree dengan consumer's attitude pada green product sebagai variabel mediasi. Variabel yang digunakan adalah green product, green price, green place, green promotion, green product purchase intention dan consumer's attitude. Penelitian ini menggunakan metode kuantitatif. Metode pengumpulan data menggunakan kuisiner yang disebar pada 400 responden yang adalah konsumen Innisfree di Jakarta dengan metode purposive sampling. Metode analisa yang digunakan adalah analisa jalur. Hasil penelitian menunjukkan bahwa green marketing mix berpengaruh positif dan signifikan terhadap consumer's attitude dan consumer's attitude berpengaruh positif dan signifikan terhadap green product purchase intention. Secara parsial green product dan green price berpengaruh positif dan signifikan terhadap green product purchase intention, green place dan green promotion tidak berpengaruh signifikan terhadap green product purchase intention. Consumer's attitude berpengaruh positif dan signifikan terhadap green product purchase intention pada produk Innisfree. Consumer's attitude memediasi penuh hubungan green place dan green promotion terhadap green product purchase intention dan memediasi parsial hubungan green product dan green price terhadap green product purchase intention.
\end{abstract}

Keywords: green marketing, green marketing mix, green product, green price, green place, green promotion, consumer's attitude, and green product purchase intention

\section{PENDAHULUAN}

Sejak beberapa dekade belakangan ini kesadaran akan pentingnya konservasi lingkungan di kalangan masyarakat mulai meningkat, hal ini tersebut dipicu dikarenakan adanya kekhawatiran yang besar terhadap kemungkinan terjadinya bencana lingkungan yang 
mengancam bukan hanya kesehatan saja namun juga kelangsungan hidup umat manusia serta rasa kemanusiaan. Masyarakat sudah mulai memiliki kesadaran akan pentingnya menjaga dan melestarikan lingkungan. Seperti yang dikemukakan Maria (2011) bahwa degradasi lingkungan (penurunan kualitas lingkungan) dan kesadaran masyarakat akan kehancuran sumber daya alam adalah isu yang sedang naik dalam dekade terakhir karena masyarakat khawatir akan dampak yang mulai timbul dari penurunan kualitas lingkungan hidup, seperti hujan asam, efek rumah kaca, polusi udara dan air yang semakin meningkat, kebakaran hutan, banjir dan penipisan lapisan ozon yang secara langsung dapat memperbesar prevelensi kanker kulit.

Kondisi di atas membuat konsumsi atas produk ramah lingkungan atau biasa disebut dengan green consumerism mulai bermunculan pada kehidupan sosial dan meningkatnya tingkat kesadaran masyarakat akan lingkungan tiap harinya, perusahaan-perusahaan mencoba untuk mengimplementasi suatu strategi pemasaran yang melibatkan kesadaran akan lingkungan atau dalam dunia akademik biasa disebut dengan green marketing. Byrne (2006) berpendapat bahwa green marketing merupakan fokus baru dalam bisnis, yang merupakan pendekatan pemasaran strategis yang mulai menempel pada setiap jenis ranah bisnis dengan memanfaatkan kesadaran lingkungan dan pengetahuan lingkungan masyarakat. Seperti yang dikatakan oleh Balawera (2013) dalam Yuliani (2016), perusahaan menerapkan isu- isu lingkungan hidup merupakan salah satu strategi dari pemasaranya. Hadirnya dinamika pasar dan perubahan orientasi dari perilaku seorang konsumen membuat perusahaan mencari cara lain dalam memasarkan suatu produk kepada konsumen (Pinondang, 2013; Yuliani, 2016).

Konsep green marketing berusaha memenuhi kebutuhan, keinginan dan hasrat konsumen dalam kaitannya dengan pelestarian lingkungan dan kesehatan. Dengan dukungan kesadaran masyarakat untuk menjaga lingkungan nya penerapan konsep green marketing sangat tepat dalam meraih minat beli konsumen. Salah satu implementasi penerapan green marketing dalam perusahaan yaitu dengan dihasilkannya green product dari suatu perusahan (Ariyanti dan Iriani, 2014). Green product adalah produk yang terbuat dari bahan daur ulang, product yang diciptakan dapat di daur ulang atau dipergunakan kembali, produk berbahan dasar alami, dan kemasan dari produk ramah terhadap lingkungan (Fonseca, 2015). Industri kosmetik dan perawatan kulit adalah salah satu industri yang turut ambil bagian dalam menciptakan green product. Penelitan akan produk ramah lingkungan tentu akan mengeluarkan biaya yang cukup besar jikalau dibandingkan dengan produk yang tidak ramah lingkungan sehingga biasanya rata-rata harga produk ramah lingkungan akan lebih mahal dibandingkan produk biasanya (green price). Kesuksesan akan penjualan green product didukung oleh green place dan green promotion yang tepat dilakukan oleh perusahaan. Selain itu karena adanya kesadaran membuat masyarakat menentukan sikapnya pada produk ramah lingkungan (consumer's attitude) dan menerapkannya pada perilakunya. Strategi green marketing melalui green marketing mix yang di dalamnya terdapat green product, green price, green place dan green promotion akan menciptakan respon positif dari konsumen sehingga akan menimbulkan minat beli konsumen. (Chatterjee, 2009)

Tujuan dari penelitian ini adalah : (1) Untuk mengetahui dan menganalisis apakah green marketing mix memiliki pengaruh yang signifikan terhadap consumer's. (2) Untuk mengetahui dan menganalisis apakah green marketing mix memiliki pengaruh yang signifikan terhadap green product purchase intention. (3) Untuk mengetahui dan menganalisis apakah consumer's attitude memiliki pengaruh yang signifikan terhadap green product purchase intention. (4) Untuk mengetahui dan menganalisis dimensi apakah dari green marketing mix yang paling mempengaruhi green product purchase intention. (5) Untuk mengetahui dan menganalisis apakah consumer's attitude memediasi pengaruh green marketing mix terhadap green product purchase intention. 


\section{KAJIAN TEORI}

Green Product. Kasali (2005) mendefinisikan, produk hijau (green product) adalah produk yang tidak berbahaya bagi manusia dan lingkungannya, tidak boros sumber daya, tidak menghasilkan sampah berlebihan, dan tidak melibatkan kekejaman pada binatang. Produk hijau (green product) adalah produk yang berwawasan lingkungan. Suatu produk yang dirancang dan diproses dengan suatu cara untuk mengurangi efek-efek yang dapat mencemari lingkungan, baik dalam produksi, pendistribusian dan pengkonsumsianya. Dari definisi di atas, dapat disimpulkan bahwa green product adalah produk yang tidak berbahaya bagi manusia dan lingkungannya, tidak boros sumber daya, tidak menghasilkan sampah berlebihan dan tidak melibatkan kekejaman pada binatang (Shaputra, 2013).

Green Price. Harga merupakan faktor penting dari bauran pemasaran hijau. Kebanyakan konsumen hanya akan siap untuk membayar nilai tambah jika ada persepsi nilai produk tambahan. Nilai ini dapat meningkatkan kinerja, fungsi, desain, daya tarik visual, atau rasa. Pemasaran hijau harus mengambil semua fakta ini menjadi pertimbangan saat pengisian harga premium. Banyak konsumen beranggapan bahwa harga produk hijau sering lebih tinggi dari pada produk konvensional (Peattie, 1995; Polonsky, 1994). Sementara ini asumsi mereka mungkin benar. Peattie (1995) berpendapat bahwa harga produk hijau tidak luar biasa mahal, namun produk konvensional realistis murah karena mereka mengecualikan sosio-lingkungan biaya produksi, penggunaan produk dan limbah. Berdasarkan definisi di atas, disimpulkan bahwa green price dalam penelitian ini merajuk pada harga produk yang memasukkan biaya perawatan dan pelestarian lingkungan sehingga harga produk lebih mahal dari produk konvensional lainnya (Peattie, 1995).

Green Place. Distribusi produk merupakan salah satu fungsi yang ketika dinyatakan hijau memiliki efek maksimum pada lingkungan. Distribusi meliputi transportasi yang hanya mungkin dengan bantuan kendaraan, yang berdampak langsung pada lingkungan. Mengadopsi kendaraan ramah lingkungan yang dimodifikasi dapat meminimalkan efek yang tidak diinginkan terhadap lingkungan dan dapat menjadi kontribusi besar dalam cara penghijauan. Maka dapat disimpulkan bahwa green place artinya adalah saluran distribusi/ berbagai kegiatan perusahaan untuk membuat produknya terjangkau dan tersedia bagi pasar sasarannya. (Kotler, 2009)

Green Promotion. Promosi berfungsi untuk menginformasikan, mempengaruhi pengambilan keputusan konsumen dan menggugah ingatan kembali konsumen (Kotler, 2009). Menginformasikan dapat berarti memberitahu kehadiran produk baru di pasar, mengusulkan kegunaan baru suatu produk, menjelaskan pelayanan yang tersedia, perubahan harga produk, cara menggunakannya, mengembangkan citra perusahaan. Mempengaruhi pengambilan keputusan konsumen atau meyakinkan konsumen dapat berarti menghimbau konsumen untuk membeli produk, meyakinkan konsumen mengenai keunggulan produk dibanding produk saingan sejenis. Jadi dapat disimpulkan bahwa green promotion adalah kegiatan promosi yang didasarkan pada startegi untuk menekankan isu-isu lingkungan (Karna, 2001).

Consumer's Attitude. Menurut Gordon Allport dalam (Nugroho, 2008), sikap adalah suatu mental dan syaraf sehubungan dengan kesiapan untuk menanggapi, diorganisasi melalui pengalaman dan memiliki pengaruh yang mengarahkan dan atau dinamis terhadap perilaku. Consumer's attitude dalam penelitian ini mengacu pada sikap konsumen terhadap produk ramah lingkungan yang merupakan persdisposisi yang dipelajari atau dibentuk dalam merespon secara konsisten terhadap lingkungan dalam bentuk suka atau tidak suka yang didasarkan pada komponen kognitif yaitu pengetahuan dan persepsi mereka mengenai masalah lingkungan, afektif yaitu emosi atau perasaan mereka terhadap lingkungan dan konotatif yaitu perilaku mereka terhadap lingkungan. (Aaker dan McLoughlin, 2010). Dari penjelasan diatas, dapat disimpulkan bahwa sikap (attitude) menunjukan apa yang konsumen suka dan konsumen tidak suka, karena sikap (attitude) merupakan ungkapan perasaan dari 
konsumen mengenai suatu objek tertentu. Sikap (attitude) juga dapat menggambarkan kepercayaan konsumen terhadap berbagai atribut dan manfaat dari objek tersebut.

Green Product Purchase Intention. Menurut Kotler (2009) dalam jurnal Hidayat (2012), mendefinisikan minat beli adalah sesuatu yang timbul setelah menerima rangsangan dari produk yang dilihatnya, dari sana timbul keterkaitan untuk mencoba produk tersebut sampai pada akhirnya timbul keinginan untuk membeli agar dapat memilikinya. Menurut Rizky dan Yasin (2014), minat beli adalah tindakan- tindakan dan hubungan sosial yang dilakukan oleh konsumen secara individu, kelompok, maupun organisasi untuk menilai, memperoleh dan menggunakan barang- barang melalui proses pertukaran atau pembelian yang diawali dengan proses pengambilan keputusan yang menentukan tindakan- tindakan tersebut. Minat beli dalam konteks green marketing ini dapat disimpulkan adalah niat atau minat untuk membeli produk atau jasa yang kurang atau tidak berbahaya bagi masyarakat dan lingkungan.

Pengaruh Green Marketing Mix terhadap Green Product Purchase Intention dengan Consumer's Attitude sebagai variabel mediasi. Menurut Morel dan Kwakye (2012) marketing mix elements (4P) berpengaruh tidak langsung terhadap consumer's attitudes. Variabel word of mouth, dan satisfaction berpengaruh langsung secara positif dan signifikan terhadap consumer's attitudes. Variabel consumer's attitudes berpengaruh langsung secara positif dan signifikan terhadap green product purchase intention. Athanasius et. al. (2015) juga mengemukakan yang sama bahwa green marketing berpengaruh positif dan signifikan terhadap sikap responden terhadap green products. Consumer attitude berpengaruh prositif dan signifikan terhadap purchase intention towards green products. Green marketing mix berpengaruh signifikan terhadap purchase intention melalui sikap terhadap green products. Dalam penelitian yang dilakukan oleh Eryani dan Wiyono (2012) menyimpulkan hasil bahwa sikap (attitude) terhadap produk kosmetik organik, berpengaruh pada minat pembelian (purchase intention) produk kosmetik organik. Athanasius et. al (2015) mengemukakan bahwa Consumer attitude berpengaruh prositif dan signifikan terhadap purchase intention towards green products. Hal ini juga diperkuat oleh penelitian yang dilakukan oleh Basumbul (2016) bahwa consumer's attitude berpengaruh positif dan signifikan terhadap purchase intention juga penelitian oleh Anwari (2017) yang menyimpulkan bahwa sikap berpengaruh positif dan signifikan terhadap minat beli. Hal ini juga diperkuat oleh penelitian yang dilakukan oleh Basumbul (2016) yang menyimpulkan bahwa green marketing berpengaruh positif dan signifikan terhadap consumer's attitude. Consumer's attitude berpengaruh positif dan signifikan terhadap purchase intention. Consumer's attitude memediasi penuh hubungan green marketing terhadap purchase intention melalui consumer's attitude.

Berdasarkan paparan di atas, maka hipotesis penelitian adalah sebagai berikut :

H1 : Terdapat pengaruh yang positif dan signifikan dari green marketing mix terhadap variabel consumer's attitude

H1a : Terdapat pengaruh yang positif dan signifikan dari dimensi green product terhadap variabel consumer's attitude

H1b : Terdapat pengaruh yang positif dan signifikan dari dimensi green price terhadap variabel consumer's attitude

H1c : Terdapat pengaruh yang positif dan signifikan dari dimensi green place terhadap variabel consumer's attitude

H1d : Terdapat pengaruh yang positif dan signifikan dari dimensi green promotion terhadap variabel consumer's attitude

H2 : Terdapat pengaruh yang positif dan signifikan dari green marketing mix terhadap variabel green product purchase intention

$\mathrm{H} 2 \mathrm{a}$ : Terdapat pengaruh yang positif dan signifikan dari dimensi green product terhadap variabel green product purchase intention 
$\mathrm{H} 2 \mathrm{~b}$ : Terdapat pengaruh yang positif dan signifikan dari dimensi green price terhadap variabel green product purchase intention

$\mathrm{H} 2 \mathrm{c}$ : Terdapat pengaruh yang positif dan signifikan dari dimensi green place terhadap variabel green product purchase intention

$\mathrm{H} 2 \mathrm{~d}$ : Terdapat pengaruh yang positif dan signifikan dari dimensi green promotion terhadap variabel green product purchase intention

H3 : Terdapat pengaruh yang positif dan signifikan dari consumer's attitude terhadap variabel green product purchase intention

H4 : Terdapat pengaruh yang positif dan signifikan dari green marketing mix terhadap green product purchase intention dengan consumer's attitude sebagai variabel mediasi

$\mathrm{H} 4 \mathrm{a}$ : Terdapat pengaruh yang positif dan signifikan dari dimensi green product terhadap variabel green product purchase intention dengan consumer's attitude sebagai variabel mediasi

$\mathrm{H} 4 \mathrm{~b}$ : Terdapat pengaruh yang positif dan signifikan dari dimensi green price terhadap variabel green product purchase intention dengan consumer's attitude sebagai variabel mediasi

$\mathrm{H} 4 \mathrm{c}$ : Terdapat pengaruh yang positif dan signifikan dari dimensi green place terhadap variabel green product purchase intention dengan consumer's attitude sebagai variabel mediasi

$\mathrm{H} 4 \mathrm{~d}$ : Terdapat pengaruh yang positif dan signifikan dari dimensi green promotion terhadap variabel green product purchase intention dengan consumer's attitude sebagai variabel mediasi

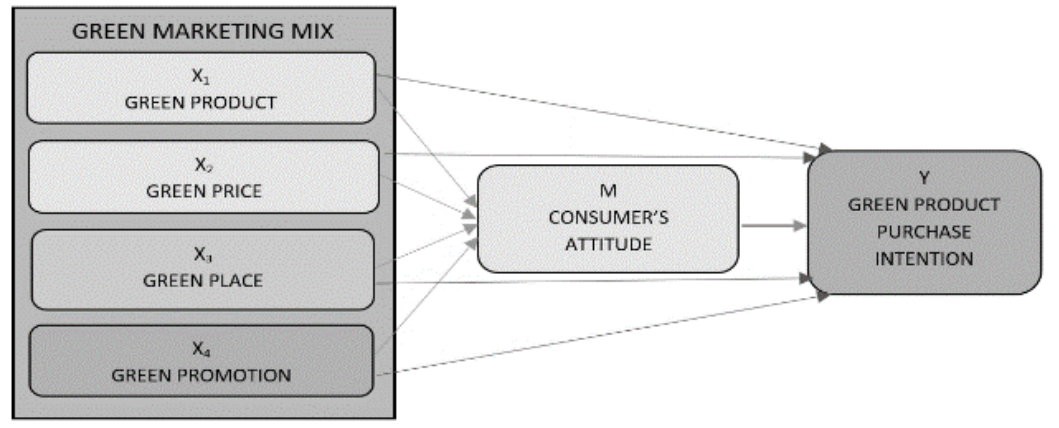

\section{METODE}

Populasi, Teknik Pemilihan Sampel, dan Ukuran Sampel. Populasi dalam penelitian ini adalah seluruh konsumen Innisfree di Jakarta. Sampel diperoleh dari konsumen Innisfree yang pernah membeli produk minimal 1 kali dalam kurun waktu 3 bulan. Metode pengambilan sampel dalam penelitian ini adalah teknik purposive sampling merupakan metode penetapan responden untuk dijadikan sampel berdasarkan pada kriteria-kriteria tertentu yang diinginkan oleh peneliti. (Siregar, 2014). Ukuran sampel yang digunakan dalam penelitian ini sebanyak 400 responden.

Variabel dan Pengukuran. Pada penelitian ini variabel green product, green price, green place, dan green promotion merupakan variabel bebas, consumer's attitude sebagai variabel mediasi serta green product purchase intention yang merupakan variabel terikat.

Tabel 1. Variabel dan Pengukuran

\begin{tabular}{lcl}
\hline \multicolumn{1}{c}{ Variabel } & $\begin{array}{c}\text { Jumlah } \\
\text { Item }\end{array}$ & \multicolumn{1}{c}{ Sumber } \\
\hline 1. Green Product & 4 & $\begin{array}{l}\text { Gunawan (2016), Angeline (2015), Pankaj \& } \\
\text { Vishal (2014), Kong et al. (2015), Silitonga } \\
(2014)\end{array}$ \\
2. Green Price & 4 & $\begin{array}{l}\text { Gunawan (2016), Angeline (2015), Silitonga } \\
(2014)\end{array}$ \\
3. Green Place & 4 & Angeline (2015), Himawan (2014) \\
\hline
\end{tabular}




\begin{tabular}{|c|c|c|}
\hline 4. Green Promotion & 4 & Angeline (2015), Himawan (2014) \\
\hline Consumer's Atttitude & 4 & Morel \& Kwayke (2012), Angeline (2015) \\
\hline $\begin{array}{l}\text { 6. Green Product Purchase } \\
\text { Intention }\end{array}$ & 4 & Harum $(2014)$ \\
\hline
\end{tabular}

Metode Analisa Data. Metode analisis data yang digunakan untuk menjawab masalah penelitian ini adalah dengan analisis jalur yang merupakan perluasan analisis linier berganda atau analisis jalur adalah penggunaan analisis regresi untuk menaksir hubungan kausalitas antar variabel (model causal) yang telah ditetapkan sebelumnya berdasarkan teori. Uji asumsi seperti uji normalitas, uji multikolineritas dan uji heterokedastisitas telah dilakukan sebelum analisis regresi berganda dilakukan dan hasilnya menunjukkan semua asumsi sudah terpenuhi. Taraf signifikansi yang digunakan dalam penelitian ini adalah 5\%. Pengujian dalam penelitian ini menggunakan program SPSS (Statistical Package for Social Science). Pada penelitian ini, pengujian untuk analisis data dilakukan dengan membagi menjadi 4 hipotesis, hipotesis pertama yaitu menguji pengaruh green marketing mix terhadap consumer's attitude, hipotesis kedua yaitu menguji pengaruh green marketing mix terhadap green product purchase intention, hipotesis ketiga yaitu menguji pengaruh consumer's attitude terhadap green product purchase intention dan hipotesis keempat yaitu menguji pengaruh green marketing mix terhadap green product purchase intention dengan consumer's attitude sebagai variabel mediasi.

\section{HASIL DAN PEMBAHASAN}

Profil Responden. Berdasarkan data yang telah dikumpulkan pada penelitian ini Sebagian besar responden dalam penelitian berjenis kelamin wanita $93.5 \%$, berusia 21 - 30 tahun sebesar $79 \%$, berpendidikan terakhir S1 sebesar 68,8\%, memiliki pekerjaan sebagai pegawai swasta sebesar 39,5\%, berpendapatan Rp.3.000.000.000 - Rp.4.999.999 sebesar 25\%, merupakan konsumen Innisfree yang membeli produk Innisfree minimal 1 kali dalam 3 bulan sebesar $63,7 \%$.

Uji Validitas dan Reliabilitas. Hasil uji validitas dan reliabilitas semua variabel penelitian terlihat dari Tabel 2 berikut ini:

Tabel 2. Hasil Uji Validitas dan Reliabilitas

\begin{tabular}{|c|c|c|c|}
\hline $\begin{array}{l}\text { Variabe } \\
1\end{array}$ & Item & $\begin{array}{c}\text { Corrected } \\
\text { item-total } \\
\text { correlation }\end{array}$ & $\begin{array}{c}\text { Cronb } \\
\text { ach } \\
\text { Alpha }\end{array}$ \\
\hline \multirow{4}{*}{$\begin{array}{c}\text { Green } \\
\text { Product }\end{array}$} & Saya menyukai produk Innisfree karena ramah lingkungan & 0,737 & \multirow{4}{*}{0,841} \\
\hline & $\begin{array}{l}\text { Saya menyukai produk Innisfree karena bahan kemasan yang } \\
\text { dapat di daur ulang }\end{array}$ & 0,628 & \\
\hline & $\begin{array}{l}\text { Saya menyukai produk Innisfree karena dibuat dari bahan- } \\
\text { bahan yang tidak berbahaya }\end{array}$ & 0,664 & \\
\hline & $\begin{array}{l}\text { Saya menyukai produk Innisfree karena menggunakan eco } \\
\text { label yang menguatkan penawaran produk sebagai produk } \\
\text { yang ramah lingkungan }\end{array}$ & 0,684 & \\
\hline \multirow{4}{*}{$\begin{array}{l}\text { Green } \\
\text { Price }\end{array}$} & $\begin{array}{l}\text { Harga produk Innisfree relatif lebih mahal dibanding produk } \\
\text { lain karena ramah lingkungan }\end{array}$ & 0,387 & \multirow{4}{*}{0,687} \\
\hline & $\begin{array}{l}\text { Harga produk Innisfree sesuai dengan manfaat yang } \\
\text { ditawarkan sebagai produk berkualitas dan aman bagi } \\
\text { lingkungan }\end{array}$ & 0,516 & \\
\hline & Harga produk Innisfree bersaing dengan produsen lainnya & 0,548 & \\
\hline & $\begin{array}{l}\text { Jika harga produk ramah lingkungan sedikit lebih murah, } \\
\text { saya akan berniat merubah gaya hidup saya dan membeli } \\
\text { produk ramah lingkungan }\end{array}$ & 0,434 & \\
\hline
\end{tabular}




\begin{tabular}{|c|c|c|c|}
\hline \multirow{4}{*}{$\begin{array}{l}\text { Green } \\
\text { Place }\end{array}$} & Jumlah gerai Innisfree sudah cukup banyak & 0,567 & \multirow{4}{*}{0,714} \\
\hline & Gerai Innisfree sudah cukup mudah dijangkau & 0,615 & \\
\hline & $\begin{array}{l}\text { Di setiap gerai Innisfree pasti tersedia lengkap produk yang } \\
\text { saya inginkan }\end{array}$ & 0,515 & \\
\hline & $\begin{array}{l}\text { Saya merasa betah digerai Innisfree karena menampilkan } \\
\text { konsep alami }\end{array}$ & 0,320 & \\
\hline \multirow{4}{*}{$\begin{array}{l}\text { Green } \\
\text { Promot } \\
\quad \text { ion }\end{array}$} & $\begin{array}{l}\text { Innisfree dalam mempromosikan produk ramah } \\
\text { lingkungannya tidak pernah mengambil keuntungan dengan } \\
\text { menipu konsumen }\end{array}$ & 0,477 & \multirow{4}{*}{0,835} \\
\hline & $\begin{array}{l}\text { Saya mengetahui pesan-pesan lingkungan yang disampaikan } \\
\text { Innisfree pada hamper setiap produknya }\end{array}$ & 0,748 & \\
\hline & $\begin{array}{l}\text { Saya menyukai produk Innisfree karena selalu } \\
\text { mengkampanyekan cinta lingkungan dan peduli masalah } \\
\text { sosial }\end{array}$ & 0,736 & \\
\hline & $\begin{array}{l}\text { Innisfree mengajak konsumen untuk ikut peduli terhadap } \\
\text { lingkungan pada setiap kegiatan promosi }\end{array}$ & 0,714 & \\
\hline \multirow{4}{*}{$\begin{array}{l}\text { Consu } \\
\text { mer's } \\
\text { Attitude }\end{array}$} & $\begin{array}{l}\text { Saya percaya pada informasi yang ada pada produk ramah } \\
\text { lingkungan Innisfree }\end{array}$ & 0,590 & \multirow{4}{*}{0,770} \\
\hline & $\begin{array}{l}\text { Saya bersedia membayar lebih mahal untuk produk ramah } \\
\text { lingkungan Innisfree }\end{array}$ & 0,500 & \\
\hline & $\begin{array}{l}\text { Saya dapat dengan mudah menemukan produk ramah } \\
\text { lingkungan di Innisfree }\end{array}$ & 0,666 & \\
\hline & $\begin{array}{l}\text { Saya menyukai promosi pada produk ramah lingkungan } \\
\text { Innisfree }\end{array}$ & 0,564 & \\
\hline \multirow{4}{*}{$\begin{array}{c}\text { Green } \\
\text { Product } \\
\text { Purcha } \\
\text { se } \\
\text { Intentio } \\
n\end{array}$} & Saya berniat membeli produk ramah lingkungan Innisfree & 0,893 & \multirow{4}{*}{0,958} \\
\hline & $\begin{array}{l}\text { Saya berkeinginan membeli produk ramah lingkungan } \\
\text { Innisfree }\end{array}$ & 0,930 & \\
\hline & Saya berencana membeli produk ramah lingkungan Innisfree & 0,922 & \\
\hline & Saya mencoba membeli produk ramah lingkungan Innisfree & 0,848 & \\
\hline \multicolumn{4}{|c|}{ 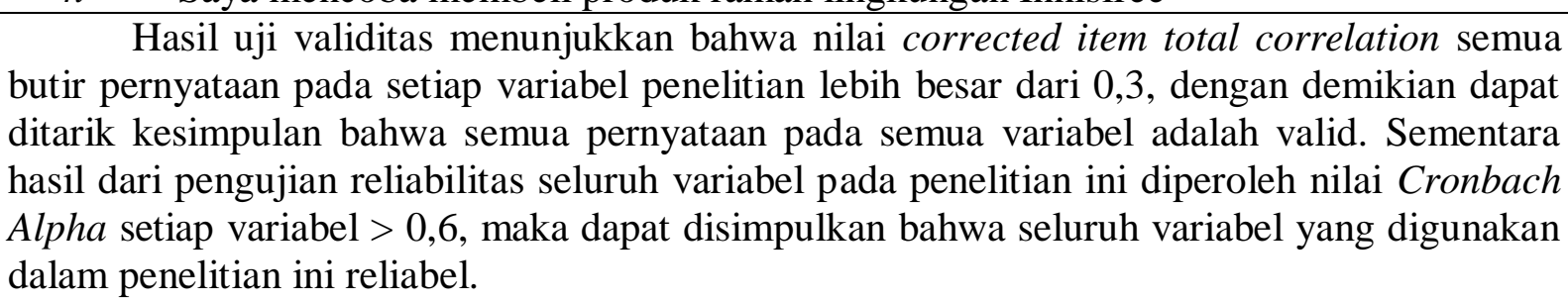 } \\
\hline
\end{tabular}

Uji Asumsi Klasik. Hasil uji asumsi klasik menunjukkan bahwa uji regresi ganda dapat dilakukan untuk menganalisis data, karena data berdistribusi normal, tidak terdapat multikolinieritas dan tidak terjadi heteroskedastisitas.

Analisis Jalur (Path Analysis). Pengujian dilakukan dengan analisis jalur (path analysis) di mana tahapan dilakukan sesuai dengan model substruktural yang telah ditentukan. Persamaan 1 digunakan untuk mengetahui pengaruh Green Product (X1), Green Price (X2), Green Place (X3), Green Promotion (X4) Terhadap Consumer's Attitude (M). Persamaan 2 digunakan untuk mengetahui pengaruh Green Product (X1), Green Price (X2), Green Place (X3), Green Promotion (X4), Consumer's Attitude (M) Terhadap Green Product Purchase Intention $(Y)$.

Tabel 3. Hasil Analisis Regresi Linear Persamaan 1

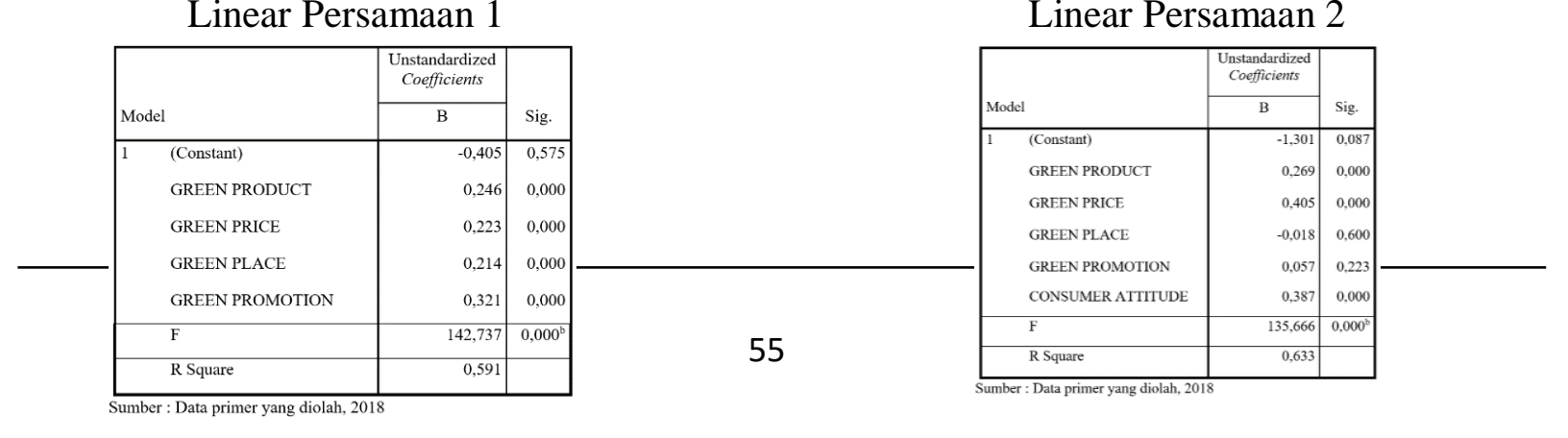

Tabel 4. Hasil Analisis Regresi Linear Persamaan 2 
Hasil analisis regresi ganda Persamaan 1 memiliki persamaan CONSUMER'S ATTITUDE $=-0,405+$ 0,246 GREEN PRODUCT + 0,223 GREEN PRICE + 0,214 GREEN PLACE + 0,321 GREEN PROMOTION + e1. Hasil uji regresi persaman 1 dapat disimpulkan bahwa variabel green promotion berperan paling besar di antara variabel lain mempengaruhi consumer's attitude. Hasil uji-F Persamaan 1 menunjukkan bahwa nilai signifikan sebesar 0,000 (lebih kecil dari $\alpha=0,05$ ), maka dapat disimpulkan bahwa paling tidak terdapat satu variabel independen yang memengaruhi consumer's attitude dengan tingkat keyakinan 95\%. Hasil uji-t atau uji hipotesis menunjukkan bahwa secara parsial semua variabel green marketing mix yang terdiri dari variabel green product $\left(\mathrm{X}_{1}\right)$, green price $\left(\mathrm{X}_{2}\right)$, green place $\left(\mathrm{X}_{3}\right)$ dan green promotion $\left(\mathrm{X}_{4}\right)$ memiliki pengaruh yang signifikan terhadap variabel consumer's attitude (M). Nilai R-Square sebesar 0,591 yang memiliki arti 59,1\% variabel consumer's attitude dapat dijelaskan oleh green product, green price, green place dan green promotion sedangkan sisanya $40,9 \%$ dapat dijelaskan oleh variabel-variabel lain yang tidak termasuk dalam penelitian.

Hasil analisis regresi ganda Persamaan 2 memiliki persamaan GREEN PRODUCT PURCHASE INTENTION $=-1,301+0,269$ GREEN PRODUCT + 0,405 GREEN PRICE 0,018 GREEN PLACE $+0,057$ GREEN PROMOTION $+0,387$ CONSUMER'S ATTITUDE. Hasil uji regresi persaman 2 dapat disimpulkan bahwa variabel green product berperan paling besar di antara variabel lain mempengaruhi green product purchase intention. Hasil uji-F Persamaan 2 menunjukkan bahwa nilai signifikan sebesar 0,000 (lebih kecil dari $\alpha=0,05)$, maka dapat disimpulkan bahwa paling tidak terdapat satu variabel independen yang memengaruhi green product purchase intention dengan tingkat keyakinan 95\%. Hasil uji-t atau uji hipotesis menunjukkan bahwa secara parsial variabel green product $\left(\mathrm{X}_{1}\right)$, green price $\left(\mathrm{X}_{2}\right)$, consumer's attitude $(\mathrm{M})$ memiliki pengaruh yang signifikan terhadap variabel green product purchase intention $(\mathrm{Y})$ sedangkan variabel green place $\left(\mathrm{X}_{3}\right)$ dan green promotion $\left(\mathrm{X}_{4}\right)$ tidak memiliki pengaruh yang signifikan terhadap variabel green product purchase intention. Nilai R-Square sebesar 0,633 yang memiliki arti 63,3\% variabel green product purchase intention dapat dijelaskan oleh green product, green price, green place, green promotion dan consumer's attitude sedangkan sisanya 40,9\% dapat dijelaskan oleh variabel-variabel lain yang tidak termasuk dalam penelitian.

Uji Variabel Mediasi. Selanjutnya pengujian variabel mediasi dilakukan dengan metode strategy causal step. Hasil uji variabel mediasi untuk pengaruh Green Marketing Mix terhadap Green Product Purchase Intention dengan dimediasi Consumer's attitude tertuang pada tabel di bawah ini :

Tabel 5. Hasil Analisis Jalur

Variabel X1 dan X2 Terhadap Y

Dengan Variabel Mediator (M)

\begin{tabular}{|c|c|c|c|}
\hline Variabel & $\begin{array}{l}\text { Lang } \\
\text { sung }\end{array}$ & $\begin{array}{l}\text { Signifi } \\
\text { kansi }\end{array}$ & $\begin{array}{ll}\text { Tida } & \text { Hasil } \\
\mathbf{k} & \\
\text { Lang } & \\
\text { sung } & \end{array}$ \\
\hline $\begin{array}{l}\text { M } \\
\text { terhadap } \\
\text { Y }\end{array}$ & 0,351 & $\begin{array}{l}\text { Signifik } \\
\text { an }\end{array}$ & - \\
\hline $\begin{array}{l}\text { X1 } \\
\text { terhadap } \\
\text { M }\end{array}$ & 0,246 & $\begin{array}{l}\text { Signifik } \\
\text { an }\end{array}$ & - \\
\hline $\begin{array}{l}\text { X1 } \\
\text { terhadap } \\
\text { Y }\end{array}$ & 0,244 & $\begin{array}{l}\text { Signifik } \\
\text { an }\end{array}$ & - \\
\hline
\end{tabular}

Tabel 6. Hasil Analisis Jalur Variabel X3 dan X4 Terhadap Y

Dengan Variabel Mediator (M)

\begin{tabular}{lllll}
\hline $\begin{array}{l}\text { Variabe } \\
\mathbf{l}\end{array}$ & $\begin{array}{l}\text { Lang } \\
\text { sung }\end{array}$ & $\begin{array}{l}\text { Signifi } \\
\text { kansi }\end{array}$ & $\begin{array}{l}\text { Tida } \\
\mathbf{k} \\
\text { Lang } \\
\text { sung }\end{array}$ & Hasil \\
& & & & \\
\hline $\begin{array}{l}\text { M } \\
\text { terhadap }\end{array}$ & 0,351 & $\begin{array}{l}\text { Signifik } \\
\text { an }\end{array}$ & - \\
Y & & & \\
\hline X3 & 0,237 & Signifik & - \\
terhadap & & an & \\
M & & & \\
\hline X3 & - & Tidak & - \\
terhadap & $\mathbf{0 , 0 1 8}$ & $\begin{array}{l}\text { Signifik } \\
\text { Y }\end{array}$ & & \\
\hline
\end{tabular}




\begin{tabular}{|c|c|c|c|c|}
\hline $\begin{array}{l}\mathrm{X} 1 \\
\text { terhadap } \\
\text { Y melalui } \\
\text { M }\end{array}$ & - & & $\begin{array}{l}0,246 \\
X \\
0,351 \\
= \\
\mathbf{0 , 0 8 6}\end{array}$ & $\begin{array}{l}\text { Partial } \\
\text { mediate } \\
d\end{array}$ \\
\hline $\begin{array}{l}\text { M } \\
\text { terhadap } \\
\mathrm{Y}\end{array}$ & 0,351 & $\begin{array}{l}\text { Signifik } \\
\text { an }\end{array}$ & - & \\
\hline $\begin{array}{l}\mathrm{X} 2 \\
\text { terhadap } \\
\mathrm{M}\end{array}$ & 0,181 & $\begin{array}{l}\text { Signifik } \\
\text { an }\end{array}$ & - & \\
\hline $\begin{array}{l}\mathrm{X} 2 \\
\text { terhadap } \\
\mathrm{Y}\end{array}$ & 0,298 & $\begin{array}{l}\text { Signifik } \\
\text { an }\end{array}$ & - & \\
\hline $\begin{array}{l}\text { X2 } \\
\text { terhadap } \\
\text { Y } \\
\text { melalui } \\
\text { M }\end{array}$ & - & & $\begin{array}{l}0,181 \\
X \\
0,351 \\
= \\
\mathbf{0 , 0 6 4}\end{array}$ & $\begin{array}{l}\text { Partial } \\
\text { mediate } \\
d\end{array}$ \\
\hline
\end{tabular}

Sumber: Data primer diolah, 2018 diolah, 2018

Berdasarkan hasil di atas ditemukan bahwa variabel Consumer's Attitude memediasi hubungan Green Marketing Mix yang terdiri atas Green Product, Green Price, Green Place, Green Promotion terhadap Green Product Purchase Intention, namun yang berbeda adalah tingkat memediasinya, di mana untuk variabel green product dan green price terjadinya partial mediation karena walau tanpa dimediasi pun variabel tersebut dapat langsung berpengaruh terhadap green product purchase intention. Namun untuk variabel green place dan green promotion terjadinya full mediation karena tidak ada hubungan langsung antar kedua variabel tersebut terhadap green product purchase intention tetapi harus melalui variabel mediasi sehingga membuat hubungan antar variabel nya menjadi hubungan tidak langsung.

Maka hasil rekapitulasi pengujian hipotesis adalah sebagai berikut.

Tabel 7. Hasil Pengujian Hipotesis

\begin{tabular}{l|c}
\hline & KESIMPULAN \\
\hline H1 & Tidak Ditolak \\
\hline H1A & Tidak Ditolak \\
\hline H1B & Tidak Ditolak \\
\hline H1C & Tidak Ditolak \\
\hline H1D & Tidak Ditolak \\
\hline H2 & Tidak Ditolak \\
\hline H2A & Tidak Ditolak \\
\hline H2B & Tidak Ditolak \\
\hline
\end{tabular}

\begin{tabular}{l|c}
\hline & KESIMPULAN \\
\hline H2C & Ditolak \\
\hline H2D & Ditolak \\
\hline H3 & Tidak Ditolak \\
\hline H4 & Tidak Ditolak \\
\hline H4A & Tidak Ditolak \\
\hline H4B & Tidak Ditolak \\
\hline H4C & Tidak Ditolak \\
\hline H4C & Tidak Ditolak \\
\hline
\end{tabular}

PENUTUP

Simpulan. Hasil penelitian ini membuktikan bahwa green marketing mix secara keseluruhan memiliki pengaruh yang positif dan signifikan terhadap consumer's attitude pada produk Innisfree di Jakarta. Secara parsial semua dimensi yaitu green product, green price, green place dan green promotion memiliki pengaruh yang positif dan signifikan terhadap consumer's attitude pada produk Innisfree di Jakarta. Green marketing mix secara keseluruhan memiliki pengaruh yang positif dan signifikan terhadap green product purchase intention pada produk Innisfree di Jakarta. Secara parsial, variabel green product dan green price memiliki pengaruh yang positif dan signifikan terhadap green product purchase 
intention, namun variabel green place dan green promotion tidak memiliki pengaruh yang positif dan signifikan terhadap green product purchase intention pada produk Innisfree di Jakarta. Consumer's attitude memiliki pengaruh yang positif dan signifikan terhadap green product purchase intention pada produk Innisfree di Jakarta. Consumer's attitude terbukti memediasi pengaruh green marketing mix terhadap green product purchase intention pada produk Innisfree di Jakarta. Namun terdapat perbedaan dalam bentuk mediasinya, di mana variabel consumer's attitude memediasi secara parsial (partial mediated) pengaruh green product dan green price terhadap green product purchase intention, dan variabel consumer's attitude memediasi secara penuh (full or complete mediated) pengaruh green place dan green promotion terhadap green product purchase intention.

Saran. Hasil penelitian ini diharapkan dapat memberikan saran kepada pihak perusahaan agar dapat memperhatikan faktor green marketing mix guna meningkatkan minat beli konsumen, terutama terus menerapkan konsep green product pada produk kosmetik dan skincare nya karena melihat faktor ini merupakan salah satu faktor terkuat yang mempengaruhi minat beli konsumen, serta juga green price nya, di mana perusahaan bisa melakukan cara-cara guna menekan harga sehingga konsumen lebih tertarik dan loyal kepada Innisfree. Serta Innisfree disarankan dapat lebih aktif dalam mengkampanyekan program peduli lingkungannya, karena melihat dari data responden, sebagian besar berada pada posisi netral dan banyak yang belum mengetahui program-program yang dicanangkan oleh Innisfree, sehingga dengan ini diharapkan masyarakat jadi mengetahui lebih banyak tentang kampanye atau program ramah lingkungan dan kegiatan sosial yang diselenggarakan oleh Innisfree dan pada akhirnya mampu membentuk sikap konsumen yang lebih positif lagi terhadap green product. Bagi peneliti lain, disarankan agar jangkauan pengambilan sampel dan cakupan wilayah diperluas lagi untuk penelitian selanjutnya, sehingga dapat memperkuat dan melengkapi penelitian sebelumnya serta menambah faktor-faktor lain yang dapat mempengaruhi minat beli pada green product.

\section{DAFTAR PUSTAKA}

Aaker, David \& Damien McLoughlin. (2010). Strategic Market Management.Chiches: John Wiley \& Sons.

Angeline, Magdalena Elisabeth. (2015). Hubungan Green Marketing Terhadap Pilihan Konsumen (Studi Kasus Pada The Body Shop Manado). Skripsi. Manado : Fakultas Pertanian Universitas Sam Ratulangi.

Anwar Hidayat. (2012). Analisis Pengaruh Kualitas Produk, Promosi dan Persepsi Harga Terhadap Minat Beli Ulang Pelanggan Voucher isi Ulang XL Di Universitas Semarang. Skripsi. Semarang : Fakultas Ekonomi Universitas Semarang.

Anwari, Farah Ulfa. (2017) Pengaruh Health Consciousness, Environmental Consciousness, dan Appearance Consciousness Terhadap Minat Beli Green Cosmetic \& Skincare Product Innisfree. Skripsi. Bandung : Manajemen Bisnis Telekomunikasi dan Informatika Universitas Telkom.

Ariyanti, K., dan Iriani, S. S. (2014). Pengaruh Persepsi Nilai dan Persepsi Resiko Terhadap Niat Beli Kosmetik Organik. Jurnal Ilmu Manajemen. Vol. 2, No. 4. 1186- 1196.

Athanasius et. al. (2015). Influence of Green Marketing toward Purchase Intention of Green Products through Attitude: Survey on Indonesian and Taiwanese Students.

Balawera, Asrianto. (2013). Green Marketing dan Social Responsibility Pengaruhnya Terhadap Keputusan Pembelian Konsumen Melalui Minat Membeli Produk Organik Di Fresh Maret Manado. Jurnal EMBA.Vol 1. Fakultas Ekonomi Dan Bisnis Universitas Sam Ratulangi http//ejournal.unsrat.ac. id/index. php/emba /artikel/view/3421. Diakses tgl 20/11/2015. Hal. 2117-2129. 
Basumbul, Ayu Nadia. (2016). Consumer's Attitudes in Mediating The Influence of Green Marketing on The Puchase Intention (A Survey in The Body Shop Lampung). Thesis. Bandarlampung : Faculty of Economics and Business The Univeristy of Lampung.

Bryne, Michael. (2006). "Understanding Consumer Preference Across Environmental Marketing Mix Variations OIKOS University of Newcastle." [Online] Diakses tanggal 01 November 2017 pukul 21.30 WIB dari http://backup.oikosinternational.org/fileadmin/oikos-

Chatterjee, S. dkk. (2009). Surveying students' attitudes and perceptions toward guidedinquiry and open-inquiry laboratories. Journal of Chemical Education, 86 (12), hlm. $1427-1432$.

Eryani \& Wiyono (2012). Pengaruh Sikap, Persepsi Kontrol Perilaku dan Norma Subjektif Pada Niat Beli Kosmetik Organik : Studi Pada Mahasiswa Universitas Sebelas Maret Surakarta. Jurnal Fokus Managerial Vol. 11, No. 2, 2012: 140 - 154.

Fonseca, J., C., G. (2015). The Impact of Green Marketing Practices On Consumer Buying Decisoin. [Thesis]. Master Dissertation In Bussiness Administration ISCTE Business School Univesity Institute of Lisbon.

Gunawan, Caterine. (2016). Pengaruh Green Corporate Perception, Eco-Label, Green Advertisement, Green Packaging, Green Product Value dan Price Terhadap Green Purchase Intention (Studi Kasus The Body Shop Jakarta)". Tesis. Jakarta : Program Pascasarjana Universitas Tarumanagara.

Harum, Stella. (2014). Pengaruh Environmental Attitudes, Social Factors, Green Product Knowledge dan Green Product Value Terhadap Green Purchase Intention (Studi Kasus : The Body Shop). Tesis. Jakarta : Program Pascasarjana Universitas Tarumanagara.

Himawan, Yuni Hananta. (2014). Pengaruh Green Marketing Perusahaan pada Pilihan Konsumen : Sebuah Tinjauan Komparatif pada Konsumen The Body Shop dengan Larissa Skin Care \& Hair Treatment di Kota Yogyakarta. Jurnal Manajemen Universitas Muhammadiyah Purworejo. Vol.10, No.2c.

Karna, Juslin. 2001. Green Advertising, Greenwash or a True Reflection of Marketing Strategies. GMI 33, 61.

Kong, W., Harun, A., Sulong, R., \& Lily, J. (2014).The influence of consumers' perception of green products on green purchase intention. International Journal of Asian Social Science,4 (8), 924-939. Retrieved from http://www.aessweb.com/pdf-files/ijass-2014 4(8)-924-939.pdf

Kotler, P. \& Keller, K.L. (2009). Manajemen Pemasaran Edisi 13 Jilid 2. Jakarta: Erlangga.

Maria, K. (2011). Attitudes and Intention toward Organic Cosmetics in Greece: An Exploratory Study. [Thesis].School of Economics and Business Administration.

Morel, M. dan Kwakye, F. (2012). Green Marketing : Consumer'sattitudes towards Ecofriendly Products and Purchase Intention in the Fast Moving Consumer Goods (FMCG) Sector. Tesis. Umea University.

Nugroho, Setiadi. 2008. Perilaku Konsumen. PT. Kencana Prenanda Media, Jakarta.

Peattie, K. 1995. Environmental Marketing Management. London : PitmanPublishing.

Polonsky, M. J. (November 1994). «An Introduction to Green Marketing. » Electronic Green Journal 1, no. 2, pp.44-53.

Rizky, M. F., \& Yasin, H. (2014). Pengaruh Promosi Dan Harga Terhadap Minat Beli Perumahan Obama PT. Nailah Adi Kurnia Sei Mencirim Medan. Jurnal Manajemen \& Bisnis, 14(02).

Shaputra, Rizky Kharismawan. (2013). Penerapan Green Marketing pada Bisnis Produk Kosmetik. Jurnal Jibeka, 7 (3). 
Silitonga, Haryati. (2014).Pengaruh Strategi Green Marketing Terhadap Keputusan Pembelian Air Minum Dalam Kemasan (AMDK) ADES Pada Mahasiswa Strata I Fakultas Ekonomi Universitas Sumatera Utara. Skripsi Fakultas Ekonomi Universitas Sumatera Utara.

Siregar, Syofian. (2014). Statistik Parametrik Untuk Penelitian Kuantitatif. Jakarta: PT Bumi Aksara.

Yuliani, J., C., dan Rahanatha.,G., B. (2016). Antesenden Niat Beli Konsumen Produk Organik Skin/Hair Care (Merek Mustika Ratu di Kota Denpasar). E-Jurnal Manajemen Universitas Udayana. Vol.5, No.8. 2302-8912. 
